\title{
Is 'Greening' the Key to Sustain in Global Market for Bangladeshi Readymade Garments Industry?
}

\author{
Naharin Binte Rab ${ }^{1} \&$ Rehnuma Hoque ${ }^{2}$ \\ ${ }^{1}$ Senior Lecturer, Department of Business Administration, East West University, Bangladesh \\ ${ }^{2}$ Lecturer, Department of Business Administration, East West University, Bangladesh \\ Correspondence: Naharin Binte Rab, Department of Business Administration, East West University, Bangladesh. \\ E-mail: naharin.ewu@gmail.com
}

Received: October 24, 2016

Accepted: December 13, 2016 Online Published: February 22, 2017

doi:10.5539/ijbm.v12n3p135

URL: https://doi.org/10.5539/ijbm.v12n3p135

\begin{abstract}
RMG (Readymade Garments) industry is life-blood for the economy of Bangladesh since she contributes around $82 \%$ in the export revenue and $14 \%$ in GDP. In the backdrop of 'Savar Building Collapse' in 2013, the second most horrifying industrial disaster of all time, the country image of Bangladesh has suffered. As a consequence of which GSP facility was withdrawn. The industry now faces a new set of challenges to sustain in the global market. Vietnam exceeded Bangladesh in apparel export to US, just last year in 2015. Another threat has been developed when Vietnam signed TPP (Trans Pacific Partnership) in February, 2016 which would leverage Vietnamese export to US market. There is pressure from US to make RMG in Bangladesh safe and sustainable. Safety pushes the cost equation up but lack of which pulls the image of the country down. Bangladesh RMG enjoys the greatest cost advantage of all the nations due to the lowest wage paid to the workers. With a standing of $\$ 25$ billion export revenue in RMG, now Bangladesh projects to reach $\$ 50$ billion in 2021. This paper would look critically into the role of greening in sustainability of the industry, in particular, reaching the 2021 target. The authors would approach critical analysis through exploratory study of academic literature and newspapers.
\end{abstract}

Keywords: Bangladesh, greening, readymade garments (RMG), sustainability

\section{Introduction}

Bangladeshi RMG industry that stands today at $\$ 25$ billion, with around $14 \%$ contribution to GDP and $82 \%$ to total export has set an ambitious goal of $\$ 50$ billion worth of RMG export by 2021.

The year 2013 appeared critical. That year had begun with the stock of a horrific fire of the last year on 23 November 2012, in Tazreen Fashions Limited. The accident cost more than one hundred lives. Tazreen Fashions Ltd. is a supplier to several world renowned retailers; namely Wal-Mart, Sears and The Walt Disney Co. Time was yet waiting to witness the 2nd most horrifying industrial disaster of all time, 'Savar Building Collapse' after the 'Bhopal Gas Tragedy' in terms of death toll where the former took 1127 lives and the latter 3787 on the spot (Note 1).

The injustice spreads through a wide network that includes factory owners, BGMEA andthe government of Bangladesh as direct and global retailers as indirect parties (Muhammad, 2015). The world's lowest wages are paid to the RMG workers of Bangladesh while Cambodia is paying double; others are also paying more than double; such as: Vietnam, India and China (Hossain et al., 2016; Siddiqui \& Uddin, 2016; Haque \& Azmat, 2015). A series of accidents in the RMG factories since 1990s is outcome of several factors: structural problem of factories; insufficiency of fire exits and fire alarms, erroneous wiring of electrical equipments, narrow stairways and exit route, weak foundation, and locked doors (Muhammad, 2015). All these primarily point fingers at the owners. Secondarily, BGMEA (Bangladesh Garment Manufacturers and Exporters Association) comes into the picture that is officially responsible for overseeing compliance and prescribing for high industrial standards rather turns out to shield the owners. That there has been no case of punishment reported for the responsible party the role and related standpoint of the government of Bangladesh is understandable. The response of government of Bangladesh in the budget of 2013-14 within two months of Savar Building Collapse is a testimony. There was no allocation in the budget either for improving rescue facilities or staff employment for factory inspection. Rather police was deployed to tackle workers' protest. (Muhammad, 2015) 
$60 \%$ of the sales for a Bangladeshi garment go to the buyers' pocket. Importing countries also earn a substantial amount in the form of import tax and value added tax. Nearly $35 \%$ account for the COGS. Therefore, less than 1\%, a tiny residue amount is left for the workers (Muhammad, 2015).

According to the report of Oxfam USA, Bangladesh pays import tariff almost $16 \%$ while United Kingdom, Saudi Arabia and France pay less than 1\%.USA gets $60 \%$ of the entire tariff paid by the LDCs from Bangladesh (Note 2). International Monetary Fund (IMF) reports Bangladesh-faces one of the highest effective tariffs, which is four to five times compared to richest economies'. According to U.S. Department of Commerce data Bangladesh paid \$750 million to USA as import duty on apparel export in 2012 (Muhammad, 2015).

On 27 June 2013 Problem further intensified when US government withdrew the GSP (Generalized System of Preference) facility for Bangladesh that the country enjoyed since 1980. This was the direct aftermath of Savar Building Collapse as President Barack Obama said,

"I have determined that it is appropriate to suspend Bangladesh ... because it is not taking steps to afford internationally recognized worker rights to workers in the country." (Note 3)

Savar Building Collapse indeed resulted in overall negative image for Bangladesh.

'Harvard University Bangladesh Development Conference 2015' reports that in response to an appeal from Bangladesh front for revival of GSP and reduction of tariff US party appeared tough. Rather, US called for sustainable and safe RMG in Bangladesh. US being the second largest export destination for RMG in Bangladesh her 'call' indeed deserve attention.

Therefore, we would attempt to explore the link between safety and sustainability per se compliance and greening on one side and competitiveness on the other for RMG in Bangladesh.

\section{Literature Review}

\subsection{History of Bangladeshi RMG}

Since 1960s the export oriented industrialization has brought economic achievements to East Asian economies. From 1960 to the mid-1990s these economies achieved high per capita growth rates, relatively low income inequality, record values of domestic savings and investments (Gereffi \& Memedovic, 2003). After the liberation war of 1971 Bangladesh also joined the fleet. Initially as an agro-based country agriculture had a great contribution over Bangladeshi GDP. But gradually the contribution has shifted to RMG (Readymade Garments) the export oriented industry that contributes the highest GDP in Bangladesh. RMG has been a key player for national development with low fixed cost and labour-intensive manufacturing (Gereffi \& Frederick, 2010). In late 1970s RMG sector started its journey as a small non-traditional exporter of Bangladesh. It was 1978 when Reaz Garments Limited first exported only $\$ 69,000$ worth RMG to USA (Rock, 2001 and Siddiqi, 2005). After 20 years of journey in 2002 Bangladesh RMG reached \$4.5 billion worth export (Siddiqi, 2005).

2.2 Scenario of Last Ten Years (2004-2005 to 2014-2015)

RMG sector contributes $14.07 \%$ of the total national GDP (BGMEA, 2016). RMG sector's total export earnings are $\$ 24.49$ billion for 2014-2015 and average growth rate is 6.15\% in the last two decades (BGMEA, 2016).

\section{NUMBER OF GARMENT FACTORIES}

W NUMBER OF GARMENT FACTORIES

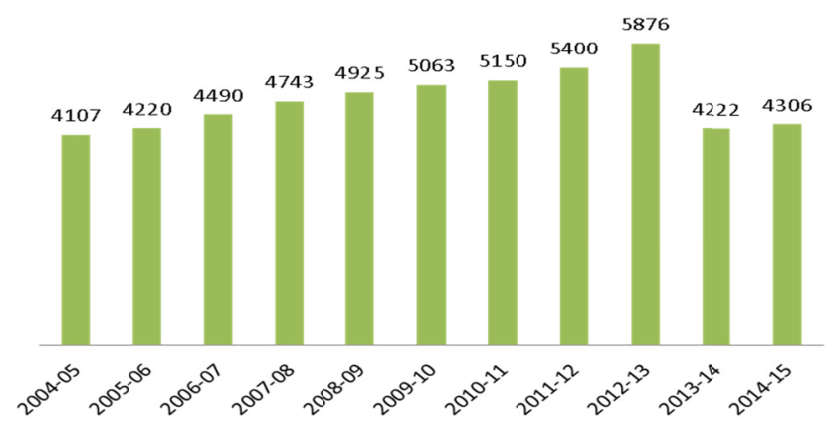

Figure1. Number of RMG factories in Bangladesh

\section{EMPLOYMENT IN MILLION WORKERS}

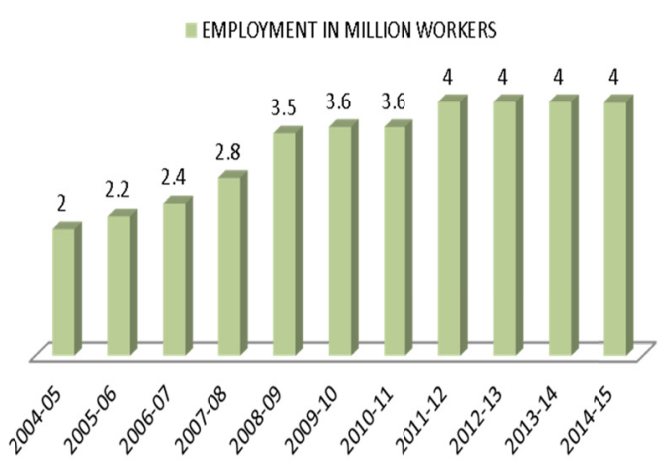

Figure 2. Employment in RMG Sector

Source: BGMEA (2016). 
RMG sector contributes $81.16 \%$ of the total export (BEPB, 2016). The industry plays a pivotal role in employment generation and contribution to the poor. Nearly 4.5 million workers of whom $80 \%$ are women are working in 4306 factories (BGMEA, 2016 and Rahman \& Siddiqui, 2015).

\subsection{Export Destination of Bangladeshi $R M G$}

RMG contributed $12.44 \%$ in the total export in $1984-85$ while $60.64 \%$ in $1992-1993$ (Siddiqi, 2005). Mahmud (2012) reported that in 2011 RMG industry helped to raise the GDP by $4.39 \%$. The credit goes to the private sector for the leadership in establishment and development of the Readymade Garment (RMG) industry which turned Bangladesh into an export oriented economy from agriculture (Sattar, 2015). Currently RMG is contributing $14.07 \%$ in GDP and $81.68 \%$ in total export.

Over $80 \%$ of the total RMG exports from Bangladesh go to The EU and the USA, making them the two major markets for Bangladeshi RMG. According to Sattar (2015) Bangladesh is gradually moving out from its reliance from European and USA market since share of export to these two markets went down from $93 \%$ to $85 \%$ in between 2009 to 2014.The following Figure:3 provides information of Bangladesh exports in USA, EU, Canada and Non-traditional markets for 2015-2016.

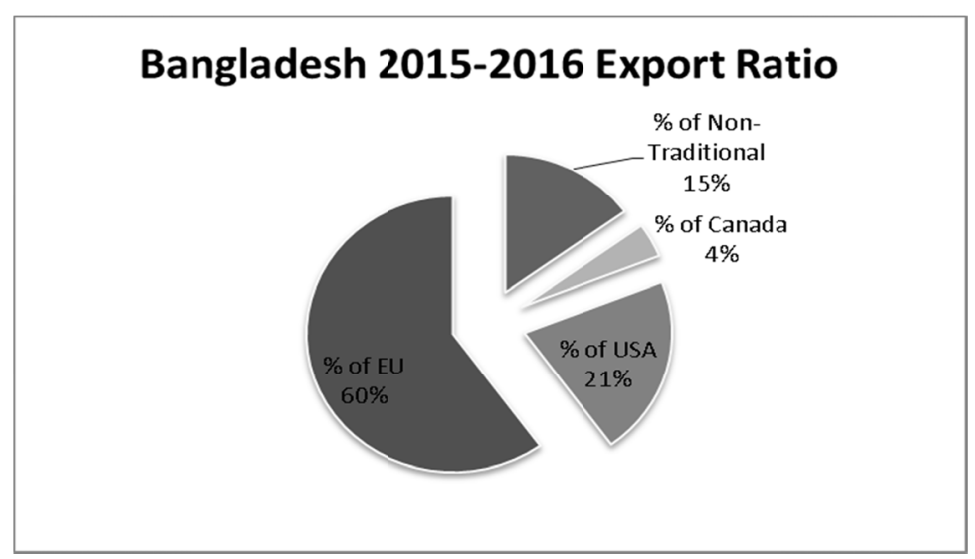

Figure 3. Bangladeshi RMG Export to world, 2015-2016. Source: BGMEA, 2016.

Mridha (2015b) emphasizes the importance of RMG sector of Bangladesh as it enjoys $5 \%$ of the world apparel business worth $\$ 450$ billion a year (Mridha, 2014). The RMG export comprises of Knitwear and Woven Garments. Uddin (2014) reported that at the initial stage USA was the major export destination with woven garments as main export item but after 2005 Europe became the major buyer. Yunus (2010) suggested that Bangladesh should move from making low value garments to the high value ones. Hasan (2013) agreed with Yunus (2010) that the diversification in the products offered by Bangladesh is absent or very low for example the low value product T-shirt is more traditional export item than the high value products like knitwear, jacket or overcoat.

\subsection{Multi-Fibre Arrangement (MFA): Bangladeshi RMG Survived the Challenge}

The Multi- Fibre Arrangement (MFA) phased out in 2005. Initially the phase out posed a challenge to the Bangladeshi RMG Industry due to emergence of Asian and African competitors (Hasan, 2013). The removal caused the USA, European Union and Canada to control the imports of textile and clothing from manufacturers from countries like China, Bangladesh, India, Sri Lanka and others (Adhikari \& Weeratunge, 2006). Despite the threat emerged from MFA removal and internal problems RMG sector kept thriving both in terms of market position and profitability (Adhikari \& Weeratunge, 2006; Hasan, 2013).

\subsection{General System of Preference (GSP): Insignificant for Bangladeshi RMG}

Aftermath General System of Preference (GSP) was suspended as punishment following the 'Savar Building Collapse' in 2013. The insignificance of GSP was identified even long before it was withdrawn. Two third of the total export to USA including RMG did not enjoy the GSP facility. Exports that enjoyed GSP facility made up less than $1 \%$ of the total export volume to USA from Bangladesh (Titumir \& Ahmed, 2006). As a reaction to the suspension of GSP ambassador Terry Miller and Ryan Olson from the US mentioned that the GSP included only 118 products and \$34.7 million worth of imports from Bangladesh in 2012 which makes the decision of withdrawal mainly punitive and off-target (Muhammad, 2015). 


\subsection{Savar Building Collapse: Pressure Mounting for Safety and Sustainability}

'Accord' was formed on May 2013, immediately after Savar Building Collapse, where more than 150 companies of 20 different countries from Europe, North America, Australia, two global trade unions, and numerous Bangladeshi unions have joined hands till date. The Accord is an agreement with the time line of five-year lawful obligation and its objective is to ensure minimum fire and building safety standards in the Bangladesh garments and textile industry (Sinkovics, Hoque \& Sinkovics, 2016). Accord had conducted independent safety inspections at 1,677 factories out of 1,800 registered factories till November 2015 and suggested right action plans mainly in the areas of fire, electrical, and structural safety (Sinkovics et al., 2016) and threatened in some worst scenario of violation, to shut down (Accord, 2015).

Another watchdog, Foreign Trade Association formed an independent institution in 2003, named BSCI that has $40 \%$ of Accord-listed suppliers (BSCI, 2014). BSCI audit is broader as it covers areas of working conditions, wages, and human rights with reference to the National Labour Act 2006 (BSCI, 2014), whereas the Accord audit mainly focuses on structural dimensions based on its own code on building and fire safety (Accord, 2015).

In 2013, again, 22 retailer groups from North America formed 'alliance' to monitor the safety of RMG workers in Bangladesh. A joint initiative was also launched after the incident by the government of Bangladesh, the ILO, the EU and the US recently followed by Canada known as the "Compact for Continuous Improvements in Labour Rights and Factory Safety in the Ready-Made Garment and Knitwear Industry in Bangladesh". The compact tries to ensure labour rights in every context for example labour union, collective bargaining, safety of health and factory buildings and ensuring ethical business behaviour.

Most of the times multinational buyers demand their suppliers to go through safety audits by private auditing organizations that they recommend, such as the BSCI and the Accord, for the reason of poor government regulatory system. Consequently, buyers have a major role in authorizing and controlling the garment sector in place of the government of Bangladesh (Labowitz \& Baumann-Pauly, 2014). 3500 RMG factories were inspected by both the Accord and Alliance and were found below the mark (The News Today, 2016). The Accord has provided red alert to 120 RMG factories if they fail to meet the standard of safety within the next couple of months. 23 RMG factories have been identified by the Accord as they could not meet the safety standard along with warning 12 more factories to experience the similar situation in case of failure to comply (The News Today, 2016).

\subsection{Concept of 'Greening'}

Burkart (2009) introduced a model of 'Green Economy' comprising six factors: Green Buildings (green retrofits for energy and water efficiency, residential and commercial assessment; green products and materials, and LEED construction), Renewable Energy, Sustainable/Clean Transportation, Water Management (Water reclamation, grey water and rainwater systems, low-water landscaping, water purification, storm water management), Waste Management and Disposal and Land Management (organic agriculture, habitat conservation and restoration; urban forestry and parks, reforestation and afforestation and soil stabilization).

In our paper the word 'Greening' refers to 'Green Building' as part of 'Green Economy'.

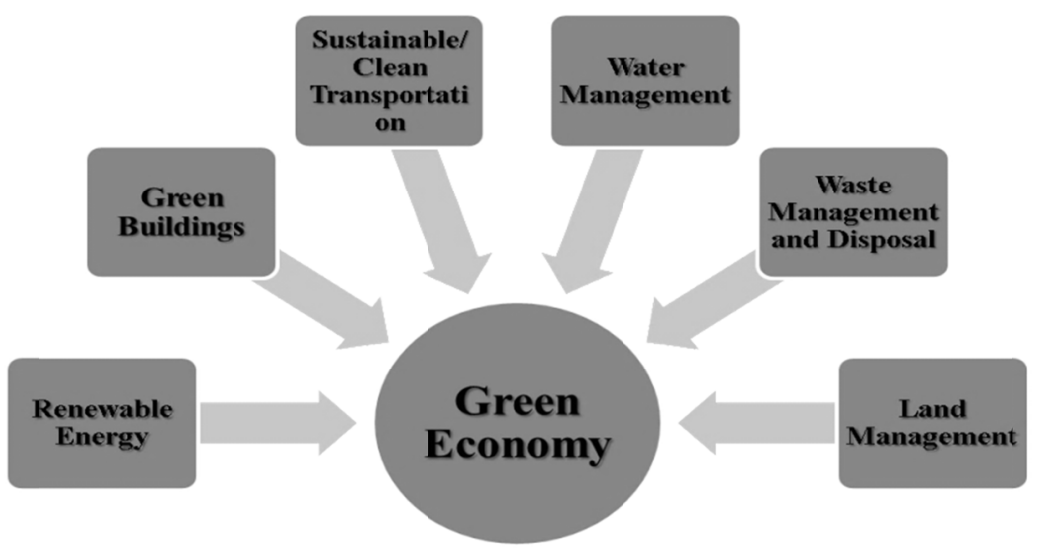

Figure 4. Green Economy model byburkart (2009) 
US Green Building Council (USGBC) defines that "Green building is a holistic concept that starts with the understanding that the built environment can have profound effects, both positive and negative, on the natural environment, as well as the people who inhabit buildings every day". Green building is an attempt to increase the positive and decrease the negative of these effects during the entire life of a building. Green building is generally considered as the planning, design, construction, and operations of buildings with special emphasis on: energy use, water use, indoor environmental quality, material section and the building's effects on its site (USGBC, n.d).

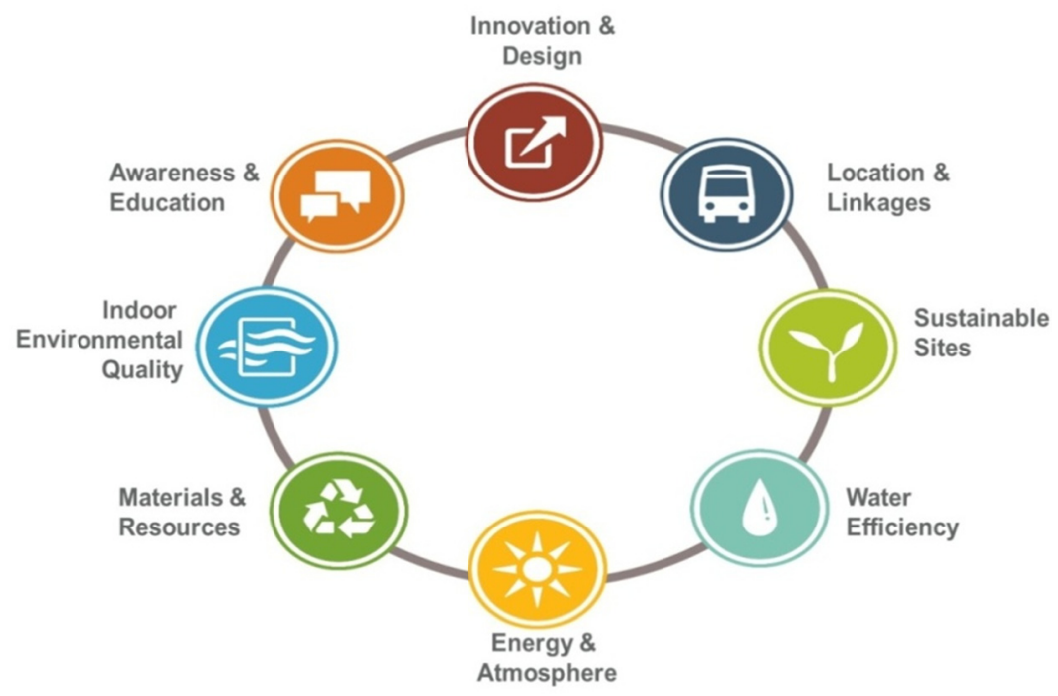

Figure 5. Green Building Indicator by US Green Building Council

USGBC was established more than 20 years ago in 1993. It has the aim to promote sustainability-focused practices in the building and construction industry. LEED (Leadership in Energy and Environmental Design) is a certification program for buildings and communities that provides framework on design, construction, operations and maintenance. Different levels of certification are available: Certified, Silver, Gold and Platinum. Leaders around the world rely on LEED, the most widely used third-party verification for green buildings. Many great green buildings ideas existed prior to LEED's development in the mid to late '90s, but there was no central mechanism for codifying them. The Garment's exporters of Bangladesh are being serious towards green building initiatives to cater the growing pressure from the eco-minded international retailers (Mridha, 2015a; Nurja, 2015). Green building is a testimony to worker safety and basic human rights.

\section{Research Objectives}

This paper aims to examine:

1. The comparative scenario of Bangladeshi RMG sector.

2. The state of greening initiatives of RMG sector and the role of 'greening' in attainment of 2021 Vision.

\section{Methodology}

This is an exploratory research done with review of existing literature, BGMEA, EPB, WB data bank and two leading newspapers in Bangladesh for period of April 2013- April 2016.

\section{Critical Discussion}

\subsection{Vietnam: The Closest Rival Identified}

McKinsey \& Company reported Bangladesh as the first choice for garment sourcing destination in two different surveys on global RMG sectors while first survey took place in 2011 on 30 Chief Purchasing Officers (CPO) of leading buyer companies and the latter took place in 2015 among 40 CPOs of top international garment retailers. Both the survey made in a five year gap reported Vietnam as the second choice for buyers making it the closest competitor and threat for Bangladesh. 


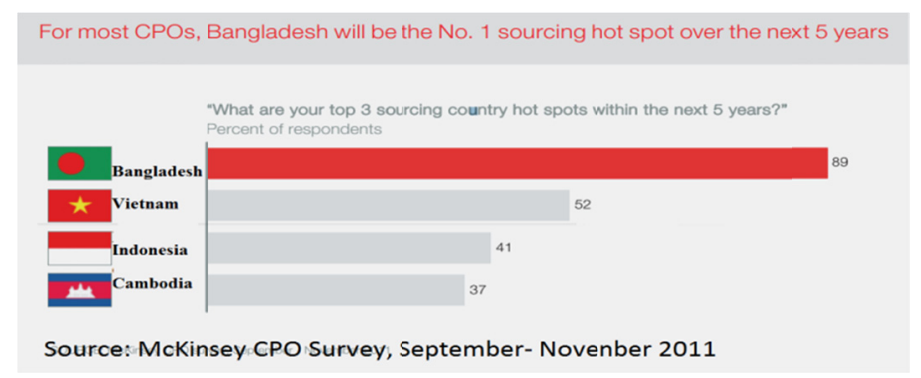

Figure 6.McKinsey survey 2011

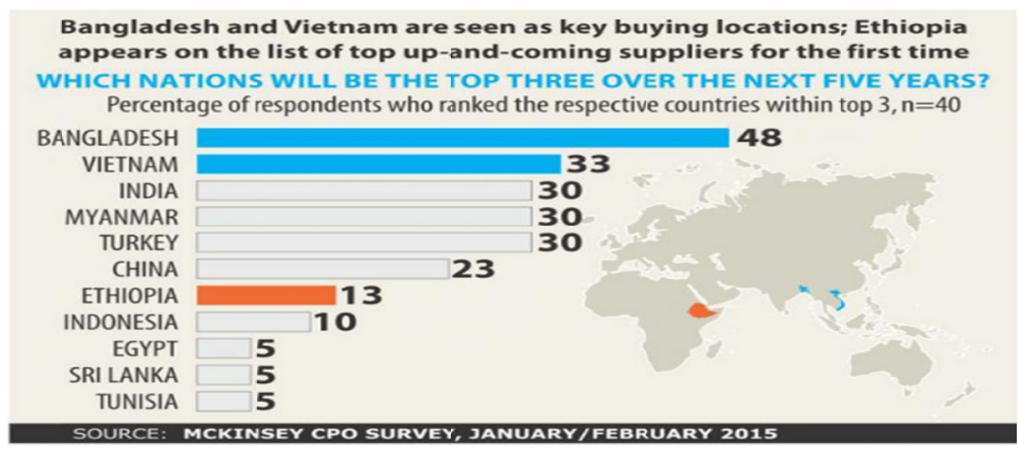

Figure 7. McKinsey survey 2015

Vietnam garment industries started its journey in early of 90s whereas the foundation of RMG sector in Bangladesh leads back to mid 70s. Below is a comparison of key macro-economic and export data of Bangladesh and Vietnam for 2014.

Table 1. Macro-economic Indicators and Export Data comparison for Bangladesh and Vietnam

\begin{tabular}{lcc}
\hline Reference Year: 2014-2015 & Bangladesh & Vietnam \\
\hline GDP per capita (current US\$) & $\$ 1,086.80$ & $\$ 2,052.30$ \\
GDP at market prices (current US\$) & $\$ 172.9$ billion & $\$ 186.2$ billion \\
GDP Growth & $6.10 \%$ & $7.10 \%$ \\
Total Export (US\$) & 31.21 million & 150 million \\
RMG Contribution in Export & $81.68 \%$ & $14 \%$ \\
Garments Export (US\$) & 25.49 million & 21 million \\
GDP Contribution from RMG & $14.21 \%$ & $11.27 \%$ \\
Population of Country & 159.07 million & 90.72 million \\
Number of Worker in RMG sector & 4 million (app) & 2.9 million (app) \\
Number of RMG Factories & 4222 & 2500 \\
\hline
\end{tabular}

Sources: World Bank Data, Fair Wear Foundation (2015), Export Promotion Bureau Bangladesh, VTAA(Vietnam Textile and Apparel Association),ILO (2015).

The macro-economic indicator shows that Vietnam was better of Bangladesh in 2014. The Per Capita GDP, Total GDP, Population in every indicator Vietnam surpassed Bangladesh in 2014.

The size of the GDP of Vietnam in 2014 was $\$ 13.3$ billion more than Bangladeshi GDP. The growth of Vietnamese GDP is also 1\% more than Bangladeshi GDP growth. If we focus on the RMG sector of these two countries, it can be said Bangladesh is more dependent on RMG sector compared to Vietnam. 14.21\% of GDP came from RMG for Bangladesh while it was $11.27 \%$ for Vietnam. $81.68 \%$ of Bangladeshi export was RMG whereas Vietnamese exports depend on RMG for $14 \%$ only. 


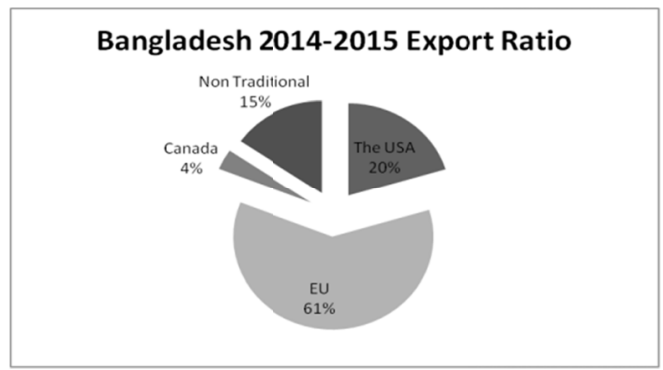

Figure 8. RMG Export to world for Bangladesh in 2014

Source: Export Promotion Bureau Bangladesh.

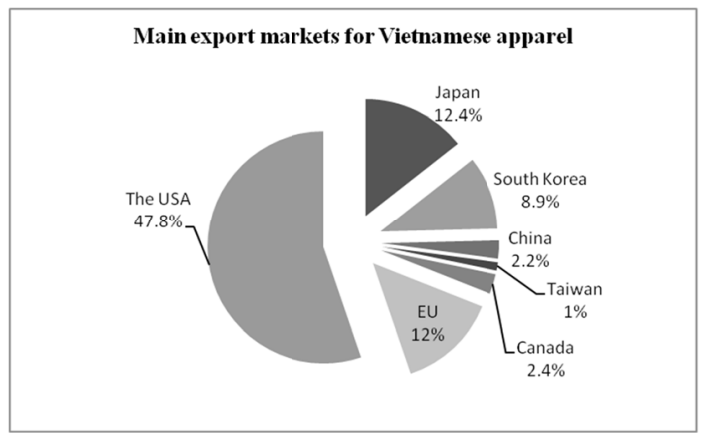

Figure 9.RMG Export to main export markets for Vietnam in 2014

Source: General Department of Vietnam Customs, 2014.

Vietnam doubled RMG export to the US market in the year 2015 overtaking Bangladesh. World Bank reports that apparel exports of Bangladesh increased by $11.41 \%$ during the first 11 months of 2015 while Vietnam grew by $14.05 \%$. In 2015 Vietnam exported $\$ 9.7$ billion worth garments while Bangladesh exported only $\$ 5$ billion to US. Vietnam started exporting to the US during the mid 90's and Bangladesh got access to the US market from the very beginning of her RMG journey.

\subsection{Capacity and Low wage: advantage for Bangladesh}

In 2013 a study of American Center for Progress (APC) reported that among the top four apparel exporters to the United States market the existing wages for garment workers in China were $36 \%$, in Vietnam $22 \%$ and in Indonesia $29 \%$ of a living wage. But in Bangladesh, prevailing wages gave workers only $14 \%$ of a living wage (ACP, 2013 American center for progress).

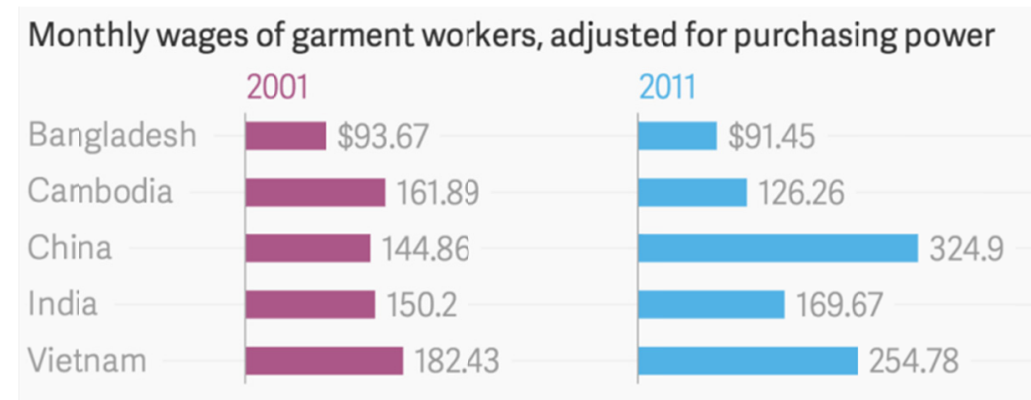

Figure 10. RMG workers' minimum wage from 2001 to 2011 among major exporting countries

Source: Center for American progress, Just jobs Network, Worker Rights Consortium

From 2001 to 2011, Bangladesh's garment workers actually experienced decrease income in terms of purchasing power, while China's wages more than doubled in during the same periods. The decline occurred in the backdrop 
of worker productivity increased in Bangladesh.

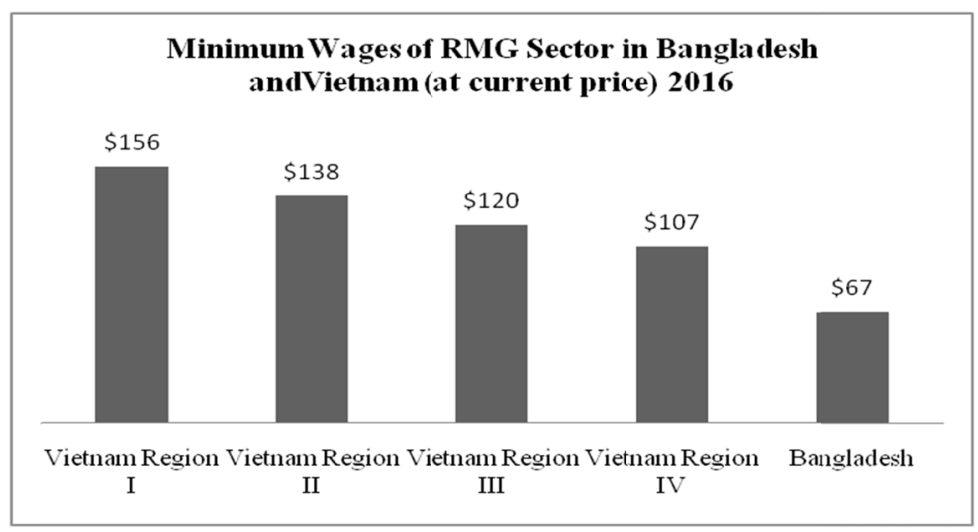

Figure 11. Minimum Wages in Bangladesh and Vietnam (at current price) in RMG sector with effect from 01-01-2016 to 31-12-2016

Source: Wage Indicator Foundation.

The above Figure is a comparison between minimum wage paid in Bangladesh and Vietnam for the year 2016. Vietnam has a different wage distribution among its four different regions. The lowest wage is paid in Vietnam Region IV which is greater than Bangladeshi minimum wage of RMG Sector (Note 4).

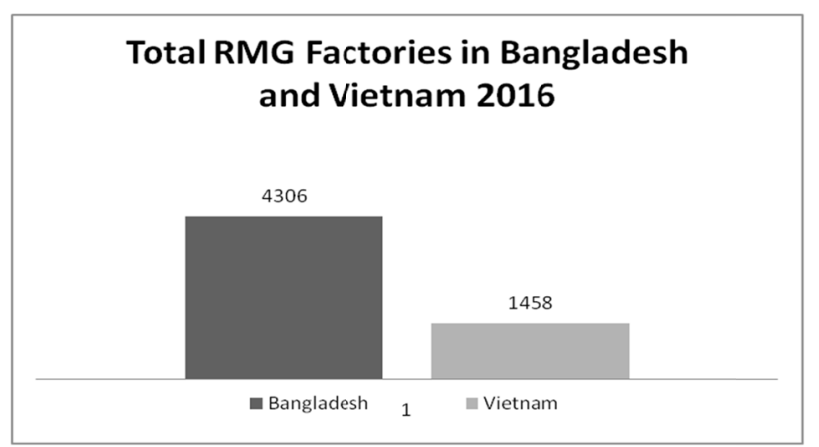

Figure 12.Number of RMG factories in Bangladesh and Vietnam 2015-2016

Source: BGMEA (2016) and VTAA (Vietnam Textile and Apparel Association).

McKinsey Survey 2011 reported that sourcing teams take their pick of sourcing country in terms of the five main criteria of price, quality, capacity, speed and risk. "Bangladesh offers the two main 'hard' advantages - price and capacity" (McKinsey \& Company, 2011, p.7). The numbers of garments factories in Bangladesh are 4306 and wage level is around $\$ 70$ making Bangladesh the first choice for buyers by providing higher capacity at lower price compared to Vietnam. Vietnam currently has 2599 garment factories and pays around \$155 of minimum wage. The capacity is double in Bangladesh and wage is half of Vietnam.

\subsection{Comparative Disadvantage for Bangladesh:TPP}

The United States, Vietnam, and ten other countries signed the Trans-Pacific-Partnership agreement on 4 February, 2016 in Auckland. The 12 nations accounting for some 40\% of the world's economy are having only two years' to ratify or reject the pact (BBC, 2016).

Bangladesh RMG sector will experience a tough time when the US led Trans Pacific Partnership (TPP) agreement will be in operation. TPP will enable Vietnam to enjoy duty-free access to the US market while Bangladesh will have to pay 15.62\% as Bangladesh is not in TPP (Mridha, 2015c). The 2014 study by University of Zhejiang's School of Economics and Management of China reported that Bangladesh is about to lose \$101.6 million of business a year due to TPP agreement. If the US reinstates withdrawn GSP facility Bangladesh RMG sector will lose competitiveness with Vietnam because the GSP covers only $0.24 \%$ of the total Bangladesh export to the US market (Mridha, 2015c). According to the BGMEA sources, Vietnam has initiated enormous expansion 
of its RMG sector. Mridha (2015c) also reported that Vietnam has a target of attracting \$3 billion foreign investments for the RMG sector in the next two years. On the opposite, in Bangladesh increase in RMG sector investment is very insignificant. Some investment worth around $\$ 200$ million per year has been made in the Export Processing Zones, which is quite insufficient to face global market challenge (Mridha, 2015c). Atiqul Islam, former president of Bangladesh Garment Manufacturers and Exporters Association also admitted that the country will lose its market share in the US to Vietnam due to TPP agreement (Mridha, 2015c). Since Vietnam has entered the ASEAN-EU Free Trade Agreement and joined the Trans-Pacific Partnership (TPP), the garments and textile industry has high hope for faster export growth in the near future(Fair Wear Foundation, 2015).

\subsection{Comparative Disadvantage of Bangladesh: Export Portfolio Less Diversified}

Bangladeshi export is heavily dependent on garments sector, more than $80 \%$ of total export of the country which means we have a very thin line of products to export other than garments. Whereas Vietnamese export depends on garment for $14 \%$ only. Our total export is one fifth of Vietnam. $80 \%$ of Vietnamese GDP comes from their export (see Table 1) while the count is $18 \%$ for Bangladesh. Bangladesh needs to diversify not only in other export items but also in garments varieties. McKinsey (2011) report says that European and US CPOs aim to increase their share of sourcing in Bangladesh by $25 \%$ to $30 \%$ in 2020 from 13\% share in 2011 through value segment plan expansion. This growth will be driven not only by an increase of volumes in current product categories but by diversifying the sourcing strategy to more complex, more stylish, or more refined items (McKinsey, 2011). So, diversification is at high importance. However because of both a heavy contributor to the country's economic growth and seen as a possible barrier to its future development, the garment industry is in an inconsistent position in this country (Belal, Cooper \& Khan, 2015).

\subsection{Comparative Disadvantage: Negative Country Image}

The disaster 'Savar Building Collapse' 2013 will remain highlighted in the pages of history leaving long lasting negative image for Bangladesh. As a serious reaction to the incident Barak Obama, president of United States suspended the GSP for Bangladesh as an act of punishment. This act is more than enough along with wide media coverage to 'Blacklist' Bangladesh as bad citizen of earth who is not only suppressing its own people but also risking the sustainability of mother earth. The negativity still continues, for example a report was presented in Harvard University Bangladesh Development Conference 2015 by International Labour Rights Forum based on a report by a team visiting Dhaka on the second year of the Rana Plaza disaster saying that there are some breaches in the management of the Rana Plaza Trust Fund, support for existing family members, and execution of the various stepstakento avoid further the incident. John Smith, Adviser and International Coordinator Textiles and Garments, UNIDO, said in the Harvard conference that another industrial accident similar to the Rana Plaza collapse will wound the Bangladeshi economy to death. Steven Greenhouse, a news correspondent for The New York Times, declared that no amount of government inspection in isolation is sufficient to ensure compliance. To overcome the negative impact Greening may play a key role.

\subsection{Compliance with Green Building: Comparative Advantage Goes with Bangladesh}

The European Commission recognized that there is 'tangible progress' in the garments sector after the Savar Building Collapse among the EU, Bangladesh government, and other partners concerned (bdnews24.com, 2016). According to USGBC 126 Bangladeshi Garment factories has already registered for LEED certification and 25 of them already got certified as of 2016. If you compare the scenario of LEED certification between Bangladesh and Vietnam, Bangladesh is found at the better position.

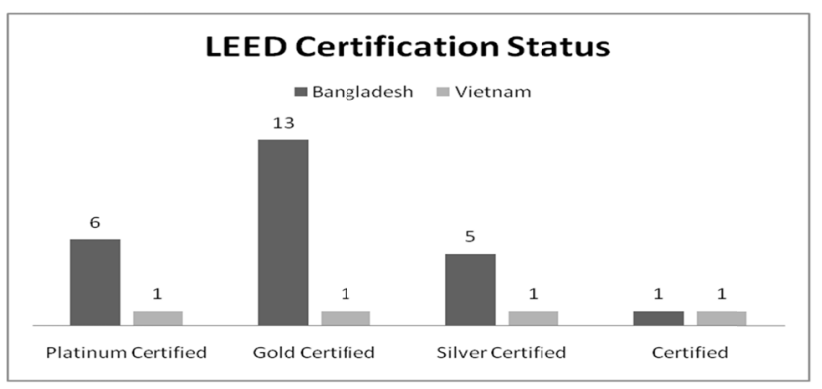

Figure 13. LEED certification status comparison between Bangladesh and Vietnam as of 2016

Source: USGBC (US Green Building Council).

Currently Bangladesh has 4306 factories and Vietnam has 2599 factories (BGMEA (2016) and VTAA, Vietnam 
Textile and Apparel Association). Among these factories Bangladesh has got 6 Platinum and 13 Gold certified factories whereas Vietnam has got only 1 Platinum and 1 Gold LEED Certified factories. Though the percentage of LEED certification for Bangladesh is also very poor but as initial stage the trend is promising.

The factories of Bangladesh are going for green building projects in order to grow further (Mridha, 2015a). Green buildings offer a range of benefits; i.e. reduction of about $24 \%$ energy consumption and $50 \%$ water consumption (USGBC, n.d).Vice president of BGMEA Shahidullah Azim said, " since Bangladeshi garment makers are going for high-end garment production, green initiatives will help a lot in building their confidence, as LEED certification indicates practice of good compliance and environmentally safe procedures". Number of Managing directors of these LEED certified Bangladeshi garments for example, David Hasanat, managing director of Viyellatex Group, Fazlul Hoque, managing director of Narayanganj-based Plummy Fashions, Zillur Rahman, managing director of Ishwardi EPZ-based Vintage Denim Studio said that green building projects are mainly initiated in Bangladesh by keeping marketing as the main mission (Mridha, 2015a). There is perception that cost of Green Building is burdensome but closer attention reveals this to be misleading (USGBC, n. d.). World Green Building Council's research shows that integration of cost strategies, program management and environmental strategies in to development process of green building lowers the cost of green building (WGBC, 2013).

Zillur Rahman, managing director of Ishwardi EPZ-based Vintage Denim Studio said to The Daily Star :

"I started the operations of the factory three years ago and now I have been receiving overwhelming responses from retailers in Europe and the US due to the green initiative,"

Through 'Greening RMG' Bangladesh can earn the confidence of retailers which will translate into more order for Bangladesh in near future.

\section{Conclusion}

37-year old Bangladesh RMG is in the midst of opportunity and threats. In the next 5 years global RMG market will experience an attractive growth of $44 \%$ which is an astounding $\$ 200$ billion; from $\$ 450$ billion in 2014 to $\$ 650$ billion estimated in 2020. Bangladesh RMG eyes into doubling her export; from $\$ 25$ billion in 2015 up to $\$ 50$ billion in 2021. It took 7 years for the industry to make a journey from $\$ 12$ billion to $\$ 25$ billion. The race for her to reach the $\$ 50$ billion mark appears intense that the industry needs to grow faster than the world growth rate.

Threats are compounding. Vietnam, the closest rival of Bangladesh RMG has doubled her export to US market in just one year from 2014 to 2015. The global landscape in the post 'Savar Building Collapse- 2013' has turned tougher to Bangladesh than earlier. International watchdogs; such as: ILO, EC are being stringent on labor rights and safety issues. There is North American buyers' alliance pushing hard the agenda further. Between Bangladesh and Vietnam, the game is not a 'zero-sum' type rather both the countries can reach their $\$ 50$ billion mark as the world RMG of 2020 can accommodate that. 'Greening' appears as a key factor for Bangladesh RMG to pacify the mounting pressure from the buyers and international watchdogs; in particular, to access the prime markets i.e. EU and US on which her dependence counts around 60 and 20 percent respectively.

\section{References}

Accord (2015). The Bangladesh Accord of fire and building safety. Retrieved from http://www.bangladeshaccord.org/

Adhikari, R., \& Weeratunge, C. (2006). Textiles and clothing sector in South Asia: coping with post-quota challenges. South Asian Yearbook of Trade and Development 2006, CENTAD, New Delhi, 109-145. Retrieved from http://www.snap-undp.org/elibrary/Publications/TextileClothingSouthAsia.pdf

BBC (2016, February 4). Trans Pacific Partnership trade deal signed in Auckland. BBC News. Retrieved from http://www.bbc.com/news/business-35480600

bdnews24.com (2016), Tangible progress made in RMG sector after Rana Plaza, European Commission says. bdnews24.com. Retrieved from http://bdnews24.com/business/2016/04/24/tangible-progress-made-in-rmg-sector-after-rana-plaza-european -commission-says

Belal, A. R., Cooper, S. M., \& Khan, N. A. (2015). Corporate environmental responsibility and accountability: what chance in vulnerable Bangladesh? Critical Perspectives on Accounting, 33, 44-58.http://dx.doi.org/10.1016/j.cpa.2015.01.005

BEPB (2016). Statistics Data.Bangladesh Export Promotion Bureau. Retrieved from http://epb.portal.gov.bd/site/files/e587b5b2-2ec8-4810-9de0-e9eea1 f0ee87/Statistic 
BGMEA. (2016). Trade information. Retrieved fromhttp://www.bgmea.com.bd/home/pages/TradeInformation

BSCI (2014). Overview of BSCI actions in Bangladesh. Business Social Compliance Initiative, Brussels, Retrieved from http://old.bsci-intl.org/system/files/overview_of_bsci_actions_in_bangladesh.pdf

Burkart, K.(2009). How to define the 'green' economy? Retrieved from http://www.mnn.com/green-tech/research-innovations/blogs/how-do-you-define-the-green-economy

European Commission (2016, April 22). Statement by Commissioners Malmström, Thyssen and Mimica on the 3rd anniversary of the Rana Plaza tragedy. European Commission. Retrieved fromhttp://trade.ec.europa.eu/doclib/press/index.cfm?id=1482

Fair Wear Foundation (2015).Vietnam Country Study 2015. Retrieved from http://www.fairwear.org/ul/cms/fck-uploaded/documents/countrystudies/othercountries/vietnam/CountryStu dyVietnam2015.pdf

Gereffi, G., \& Frederick, S. (2010). The Global Apparel Value Chain, Trade and the Crisis: Challenges and Opportunities for Developing Countries. In O. Cattaneo, G. Gereffi \& C. Staritz (Eds.), Global Value Chains in a Postcrisis World (pp. 157-208). Washington, DC: World Bank. Retrieved from http://unstats.un.org/unsd/trade/s_geneva2011/refdocs/rds/apparel\%20industry\%20and\%20crisis\%20(gereff i\%20-\%20apr\%202010).pdf

Gereffi, G., \& Memedovic, O. (2003). The Global Apparel Value Chain: What Prospects for Upgrading by Developing Countries, UNIDO Strategic Research and Economics Branch, Vienna. Retrieved from http://www.ids.ac.uk/ids/global/pdfs/AppareF1.pdf

Haque, M. Z., \& Azmat, F. (2015). Corporate social responsibility, economic globalization and developing countries: A case study of the ready made garments industry in Bangladesh. Sustainability Accounting, Management and Policy Journal, 6(2), 166-189.http://dx.doi.org/10.1108/SAMPJ-04-2014-0028

Hasan, J. (2013). The Competitiveness of Ready Made Garments Industry of Bangladesh in Post MFA Era: How Does the Industry Behave to Face the Competitive Challenge? British Journal of Economics, Management \& Trade, 3(3), 296-306. $\quad$ Retrieved from https://zenodo.org/record/8367/files/1374390219-Hasan332013BJEMT4321.pdf

Heshmati, A. (2014). An Empirical Survey of the Ramifications of a Green Economy. Discussion Paper No 8078. Institute for the Study of Labor (IZA). Retrived from: http://repec.iza.org/dp8078.pdf

Hossain, M. M., Alam, M., Hecimovic, A., Hossain, M. A., \& Lema, A. C. (2016). Contributing barriers to corporate social and environmental responsibility practices in a developing country: A stakeholder perspective. Sustainability Accounting, Management and Policy Journal, 7(2), 319-346.http://dx.doi.org/10.1108/SAMPJ-09-2014-0056

Labour Behind Label. (2013).Bangladesh building collapse kills over 1100 workers: Primark and Mango labels found. Retrieved from http://www.labourbehindthelabel.org/urgent-actions/item/1140-bangladesh-building-collapse-kills-over-80workers-primark-and-mango-labels-found

Labowitz, S., \& Baumann-Pauly, D. (2014). Business as usual is not an option: supply chains and sourcing after Rana Plaza. NYU Stern School of Business, New York, NY. Retrieved fromhttp://www.stern.nyu.edu/sites/default/files/assets/documents/con_047408.pdf

Mahmud, R. B. (2012). Skills development in Bangladesh RMG sector. The News Today. Retrieved from http://www.newstoday.com.bd

McKinsey. (2011). Bangladesh's readymade garments landscape: the challenge of growth. Retrieved fromhttps://www.mckinsey.de/files/2011_McKinsey_Bangladesh.pdf

McKinsey. (2015). Sourcing in a volatile world: The East Africa opportunity. Retrieved fromhttp://www.mckinsey.com/industries/retail/our-insights/sourcing-in-a-volatile-world-the-east-africa-op portunity

Mridha, R. U. (2014, December 04). Building blocks of garment industry. The Daily Star. Retrieved from http://www.thedailystar.net/building-blocks-of-garment-industry-53255

Mridha, R. U. (2015a, April 21). Garment exporters going green to grab more orders. The Daily Star. Retrieved from http://www.thedailystar.net/business/garment-exporters-going-green-grab-more-orders-77426 
Mridha, R. U. (2015b, May 04). Bangladesh: still the first choice for apparel sourcing after China. The Daily Star. Retrieved from http://www.thedailystar.net/business/bangladesh-still-the-first-choice-apparel-sourcing-after-china- 80350

Mridha, R. U. (2015c, June 26). Garment exports to US will not be hurt by Trans-Pacific agreement: Economist. The Daily Star. Retrieved from http://www.thedailystar.net/business/garment-exports-us-will-not-be-hurt-trans-pacific-agreement-economis $\mathrm{t}-103027$

Muhammad, A. (2015, March 08). Bangladesh garments: Crisis and challenges. The Daily Star. Retrieved from http://www.thedailystar.net/bangladesh-garments-crisis-and-challenges-4797

Nurja, S. (2015, April 19). LEED Certification for 15 Garments Factories. Textile Tribune. Retrieved from http://www.textiletribune.com/2015/04/leed-certification-for-15-garments.html

Rahman, M. H., \& Siddiqui, S. A. (2015). Female RMG worker: Economic Contribution in Bangladesh. International Journal of Scientific and Research Publications, 5(9), 1-9. Retrieved from http://www.ijsrp.org/research-paper-0915/ijsrp-p4579.pdf

Research Initiative for Social Equity Society. (2014). The Bangladesh labor law (amendment) bill 2013 passed in the parliament. Retrieved from http://risebd.com/2013/07/16/the-bangladesh-labor-law-ammendmend-bill-2013-passed-in-the-parliament/

Rock, M. (2001). Globalization and Bangladesh: The Case of Export Oriented Garment Manufacture. South Asia: Journal of South Asian Studies, 24(1), 201-225. http://dx.doi.org/10.1080/00856400108723430

Sattar, Z. (2015). Strategy for Export Diversification 2015-2020: Breaking into new markets with new Policy Research Institute of Bangladesh. Policy Research Institute of Bangladesh. Retrieved from http://www.plancomm.gov.bd/wp-content/uploads/2015/02/7_Strategy-for-Export-Diversification.pdf

Siddiqi, H. G. A. (2005). The Readymade Garment Industry of Bangladesh. Dhaka: University Press Limited

Siddiqui, J., \& Uddin, S. (2016). Human rights disasters, corporate accountability and the state: Lessons learned from Rana Plaza. Accounting, Auditing \& Accountability Journal, 29(4), 679-704. http://dx.doi.org/10.1108/AAAJ-07-2015-2140

Sinkovics, N., Hoque, S. F., \& Sinkovics, R. R. (2016). Rana Plaza collapse aftermath: are CSR compliance and auditing pressures effective? Accounting, Auditing \& Accountability Journal, 29(4), 617-649. http://dx.doi.org/10.1108/AAAJ-07-2015-2141

Stavrakakis Y. (1997). Green ideology: A discursive reading. Journal of Political Ideologies, 2(3), 259-279. http://dx.doi.org/10.1080/13569319708420763

The News Today. (2016, January 13). Vietnam beats Bangladesh in RMG export. The News Today. Retrieved from http://www.newstoday.com.bd/index.php?option=details\&news_id=2432473\&date=2016-01-13

Titumir, R. A. M., \& Ahmed, M. I. (2006). Demystifying Effectiveness of Market Access for LDCs A Case Study of Bangladesh Apparel Exports to the USA. Unnayan Onneshan-The Innovators.

Uddin, M. M. (2014). How Bangladeshi Ready Made Garments Industry can be competitive in the global Market. $\begin{array}{lllll}\text { Business Economics } & \text { Tourism } & \text { Retrieved }\end{array}$ fromhttps://www.theseus.fi/bitstream/handle/10024/80218/final\%20edition.pdf?sequence=1

USGBC. (n.d). U.S. Green Building Council. Retrieved from http://www.usgbc.org/

WGBC (2013). The business case for green building. World Green Building Council. Retrieved fromhttp://www.worldgbc.org/files/1513/6608/0674/Business_Case_For_Green_Building_Report_WEB_2 013-04-11.pdf

Yunus, M. (2010). Knitwear Industry in Bangladesh: A Case Study of Firms in Narayanganj. Bangladesh $\begin{array}{lllll}\text { Institute of Studies } & \text { Development }\end{array}$ fromhttp://www.ihdindia.org/\%5C/Formal-and-Informal-Employment/Paper-7-Knitwear-Industry-in-Bangl adesh-A-Case-Study-of-Firms-in-NarayanGanj.pdf

\section{Notes}

Note 1.http://io9.gizmodo.com/the-most-horrifying-industrial-disasters-of-all-time-506430995

Note 2.U.S. Department of Commerce data. 
Note 3.http://www.reuters.com/article/us-obama-trade-bangladesh-idUSBRE95R08D20130628

Note 4.The wages here are calculated with the exchange rate of US dollar (USD) to Bangladeshi Taka and Vietnamese Dong as of 18/05/2016.

\section{Copyrights}

Copyright for this articleis retained by the author(s), with first publication rights granted to the journal.

This is an open-access article distributed under the terms and conditions of the CreativeCommons Attribution license (http://creativecommons.org/licenses/by/4.0/). 